\title{
How the Electronic Commerce Enterprise Attract More Customers
}

\author{
Jianyong Bai \\ College of Economics and Management, Zaozhuang University, Zaozhuang 277160, China \\ 157003974@qq.com
}

\begin{abstract}
The customer of the enterprise is the source of profits and the foundation of the enterprise survival and development. In the background of buyer's market, the demands of consumer become more diversification and individuation. How can the electronic commerce enterprise attract more customers has become more and more important. Especially those who have not shop on the Internet. In the age of Internet economy, individual consumers are increasingly differentiation and network products are more colorful, so the enterprises put forward higher request to maintain customer. Based on the analysis of individual characteristics of the consumer spending, this paper puts forward some suggestions of enterprise developing network marketing.
\end{abstract}

Keywords: the Network Marketing; the Electronic Commerce Enterprise; Customer.

\section{Introduction}

With the development of China's e-commerce, more and more enterprises have established their own e-commerce website on the Internet. Enterprises are faced with more complex network environment. $\mathrm{n}$ the age of Internet economy, marketing activities of enterprises breakthroughs the original goods sales scope and consumer groups, gets rid of the traditional marketing rely on strict sales channel, Stretches the concept of time and space. The environment of network marketing change greatly, so on the network marketing has its unique features: one is the rapid growth of the consumer groups, with the rapid development of China's Internet, in recent years the number of Chinese Internet users grows quickly. As at Dec. 30, 2014 China's Internet users totaled 649 million, Internet penetration rate is $47.9 \%$, which bring enormous market space to the marketing activities of enterprises. On the other hand is the steady growth of e-commerce transactions. In 2014 the whole society of our country e-commerce transactions amounted to 16.39 trillion yuan, so the marketing activities of enterprises have very big development space.

\section{Customer classification}

For China's e-commerce enterprises, consumers are divided into two types. The first type is the consumer that has not bought any goods on the Internet. They accounted for $73.4 \%$ of the total population in China. One part of these consumers has little or no access to the Internet, so they know little about the Interne and network shopping. The other consumers often use the Internet, but for some reason they don't shop on the Internet.

The second types are consumers who often buy things on the Internet. They accounted for $26.6 \%$ of the total population in China, and in 2014, Chinese online shopping market transactions reached 2.8 trillion yuan, growth of $48.7 \%$. So the electronic commerce enterprises have very big development space.

\section{Non Online Shopping Consumers}

\subsection{Characteristics of Non Online Shopping Consumers}

The first type is the consumer that has not bought any goods on the Internet. The characteristics of this type of customers are mainly the following three points

(1) They have no access to the Internet

In these People's daily life, due to age, knowledge, network coverage and other reason, they can't use the Internet properly. At present, this situation has a great relationship with our country's network 
infrastructure construction and people's living standards. In the last few years, with the development of smart phones and the popularity of $4 \mathrm{G}$ networks, the threshold of online shopping has been very low.

(2) They don't believe in network or network shopping.

Although these people can access the Internet, because of age, ideas and other reasons they do not believe the Internet. They think that the Internet is illusory, and the network is illusory. They don't believe they can buy what they want through the Internet. On the one hand they are worried about the quality of goods, on the other hand they are concerned about the security of funds on the network.

(3) They don't meet the requirements of online shopping.

Online shopping consumers first need a website member account, next need a network payment account, and finally a reasonable distribution address. Some people do not have any network accounts, some people do not have a bank card or network payment functions, and some people's distribution is not in the logistics company's distribution range. Even if these people can access the Internet, but the lack of these necessary conditions, they cannot complete the network shopping. Even if the three conditions are satisfied, they are also concerned about the security of online shopping and security of distribution.

\subsection{Countermeasures for Non Online Shopping Consumers}

(1)Reduce the conditions for online shopping

Website design should be from the perspective of the user; the shopping process of website should be simplified. Security of online shopping payment and diversity of online shopping payment should be improved. Only in this way, the number of shopping online shopping will continue to increase

(2)Use of traditional media for propaganda

It is very difficult to changing a person's spending habits. Online shopping is changing a lot of people spending habits. In the face of a large number of ordinary consumers, e-commerce companies need to use more traditional marketing methods to get a large number of users. In the last few years, a large number of TV ads have brought a lot of users to e-commerce. So the use of some traditional marketing methods can effectively improve the number of consumers to e-commerce sites

(3) Appropriate incentives or benefits for new users

For E-commerce enterprises, how to acquire large quantity of high quality and trusted customers is the key for positive business development. Consumers' first online shopping often requires a little motivation, so e-commerce companies have to spend money to attract new customers. For example, a certain cash incentives to new users, a certain discount to new customers, to a certain percentage of new users of free shopping opportunities, etc.

\section{Online Shopping Consumers}

\subsection{Characteristics of Online Shopping Consumers}

The second types are consumers who often buy things on the Internet. Due to the development of the network and life rhythm, more and more consumer especially some young people to start using the network the choose and buy goods that he needs, compared with the non online shopping consumer behavior, network consumers' consumption psychology and the consumer behavior of there are rather different. The specific performance of the following aspects:

(1) Consumers demand for personalized enhancements

In the network economy, the consumer is marketing activities of active party, according to their own requirements consumers looking for goods that he needs on the Internet. The kind of large-scale industrial economy and the homogenization of the goods do not meet the individual needs of the consumers, so the business must quickly meet the individual needs of the consumers through market research.

(2) Consumers purchase randomness increased

Whether individual consumers or business customers now are particularly critical, because in the Internet economy, there are numerous competitors around the world, when the needs of the users can't 
meet, the customer as long as clicking a mouse, it is possible to put into the arms of competitors, and lose enterprise customers resources. Individual consumers on the network are mostly non-professional. Their decisions are very vulnerable to enterprise advertising and other means of sales promotion tactics, lead to increased shopping randomness.

(3) Consumers buying behavior tend to miniaturization

In modern society, as family size is shrinking and consumers' demands are different, consumers present the characteristics of small purchase. In addition, that citizens live in apartment and their storage space are limited, lead to the quantity of network consumers' single buying reduced, but the number of purchase increased.

(4) Consumers buying convenience increase

In the traditional marketing era, the whole process of purchase consists of looking at samples, choosing goods, confirming the payment, packaging goods, taking delivery of goods and so on, therefore consumers need to spend a lot of time. Furthermore the heavy traffic and increasing stores make shopping time extended a lot. However, in network marketing era, consumers can choose and buy the goods and services they need at home, which greatly improve the efficiency of the shopping.

(5) Consumers pay more attention to communication

In the traditional marketing era, consumers and firms lack the communication channel between each other. Most enterprises follow the market leader to research and produce products. Because of not familiar with the needs of the consumers, many products are not sold very well. However, in the network marketing era, consumers participate in the whole process of product design and development, production, sales, service and so on through the network. Owing to communicating with the enterprise at any time, the consumers can buy the commodities really satisfy their individual needs.

\subsection{Countermeasures for online shopping consumers}

In the network marketing era, the consumers' behavior characteristics have changed greatly, so the enterprises are necessary to research these changes and improve customer loyalty. The enterprises should analyze the cause of these new consumers' behaviors feature, and then take the scientific, effective marketing strategy.

(1) Strengthen the website construction and promotion of the enterprise. The corporate website is the center of the network marketing, Search engine, trading platform, and other promotions around the corporate website. Many network marketing companies ignore their own site building, maintenance and updating, which make difficult for consumers to understand the business and its related products and services. Therefore, enterprises should use web platform、 search engine and trading platforms to promote the corporate website.

(2) Display and describe goods accurately. Distribute qualified goods within the promised time. As the network shopping process, consumer know a little information of goods, lack intuitive understanding of goods. Consumers have some doubt on the authenticity and quality of goods, greatly limits the consumer to purchase goods on the network. In the distribution process, whether the prescribed time arrived safely, whether can provide the goods in transit transport information query, but also the requirements of modern network marketing business.

(3) Build a platform to communicate with consumers for example BBS, chat room, QQ group, discussion groups. In the network era, consumers and business communicate more and more freedom. Through this platform, the enterprise can understand customers' needs effective and timely, so the enterprise can meet customer increasingly changing needs. The enterprise can obtain various criticisms and suggestions of consumers. Enterprise chooses reasonable suggestions and provides solutions timely and effectively, so the enterprises improve the quality of the product or service to enhance the customer loyalty.

(4) Build a variety of online payment platform to improve the security of the network shopping. The biggest difference between the network marketing and traditional marketing is the online payment; the enterprise should pay attention to build a variety of online payment platform. It is very convenient for consumer online payment behavior. At present the main domestic online payment is a 
bank card online payment and the third-party payment. The third-party payment platform has two categories. The first category is gateway-type third-party payment platform, ShouXin is typical of it. The other is credit guarantee third-party payment platform; pay treasure is typical of it. At the same time in the network pay process, enterprise should ensure the safety of the payment, which mainly includes the authenticity of the identity of sides of transactions, the privacy and security of trading information. Only in this way, individual consumers can feel secure.In the age of Internet economy, the enterprise can use some strategy on product information, information service, distribution mode, trading platform and communication to win more customers, in order to ensure that the enterprise have a good performance in the consumer market.

\section{Summary}

Along with the rapid development of the Internet, more and more consumers begin to try online shopping. This paper in the full analysis the characteristics of the non online shopping consumers and online shopping consumers, on this basis, the companies proposed marketing. Expect to be able to provide some reference value to the enterprise network marketing.

\section{References}

[1].Cravens, Oliver E. G. \&Ramamoorti The Reputation Index:Measure and Managing Corporate Reputation[J]. European Management Journal,Apri1 2003

[2].Corstjens,M.\&Lal,R. Building Store Loyalty through Store Brands[J]. Journal of Marketing Research,2000,37(3)

[3].Hoffman D.L,Novak T.P,Peralta M. Building consumer trust online[J]. Communications of the ACM,1999,42(4) 